\title{
Enzyme Inhibition Activity Both in vitro and in silico Screening of Triphala Plant Extracts on Phospholipase $A_{2}$
}

\author{
Satyanarayana Murthy Malladi ${ }^{1, *}$, Nagendra Sastry Yarla ${ }^{2}$, Devendra Kumar Pandey ${ }^{3}$ \\ 'Department of Botany, Lovely Professional University, Phagwara, Punjab, INDIA. \\ ${ }^{2}$ Novel Global Education Foundation, NSW, AUSTRALIA. \\ ${ }^{3}$ Department of Biotechnology, Lovely Professional University, Phagwara, Punjab, INDIA.
}

\begin{abstract}
Objectives: The present work was aimed to determine the effect on the Phospholipase A2 (PLA2) enzyme and conduct its antioxidant nature, phytochemical analyses of the Triphala compound's extract, an Ayurvedic Rasayana made from Terminalia chebula, Emblica officinalis and Terminalia bellirica and also, the molecular docking study. Methods: Twelve Triphala compounds are extracted from Gas chromatography-mass spectrometry, Phytochemical study, the Triphala's inhibitory effect on antioxidant property and PLA ${ }_{2}$ assay. To study each compound's degree by docking software like iGEMDOCK, Auto dock Vina, and overlapping on the PLA2 enzymes like Naja naja, Human sPLA2, Bee and Scorpion venoms phospholipase. Results: Phytochemical screening revealed the presence of phenolics, alkaloids, saponins, flavonoids and tannins. Methanolic extract of Triphala fruit powder also showed good scavenging ability compared to the superoxide. $\mathrm{IC}_{50}$ value of seed powder extract is $23.12 \mu \mathrm{g} / \mathrm{ml}$ whereas standard, i.e. superoxide is at $32.66 \mu \mathrm{g} / \mathrm{ml}$, respectively. $\mathrm{IC}_{50}$ scavenging activity was 31.18. $\mu \mathrm{g} / \mathrm{ml}$ and $32.66 \mu \mathrm{g} / \mathrm{ml}$ standard, respectively. Moreover, it shows
\end{abstract}

a better interaction of bioactive compounds with the PLA2 enzyme. Morin $\left(3,5,7,2\right.$ ', $5^{\prime}$-Pentahydroxyflavone) 9,10 anthraquinone was found to be a better inhibitor among the compounds, with a binding energy $-82.6534 \mathrm{~K}$. $\mathrm{cal} / \mathrm{mol},-73.9662 \mathrm{~K} . \mathrm{cal} / \mathrm{mol}$ respectively and hydrogen bonding with PRO61 and ARG-59, the primary amino acid residues at the active site of PLA2. Conclusion: The study will allow the Triphala compounds that contain lead in oncological therapy and other inflammatory diseases to be improved. Key words: Inflammation, Triphala, Molecular Docking, Phospholipase $A_{2^{\prime}}$ Gas chromatography-Mass spectrometry, DPPH radical scavenging activity.

\section{Correspondence}

Mr. Satyanarayana Murthy Malladi

Ph.D. Scholar, Department of Botany, Lovely Professional University, Phagwara, Jalandhar-144001, Punjab, INDIA.

Email: snmmalladi5@gmail.com

DOI: 10.5530/ijpi.2021.2.29

\section{INTRODUCTION}

Extensive research has pursued the development of Phospholipase $\mathrm{A}_{2}\left(\mathrm{PLA}_{2}\right)$ inhibitors as a potential anti-inflammatory enzyme. ${ }^{1}$ Nonsteroidal anti-inflammatory drugs (NSAIDs) were of scrutiny for the last few decades for their efficiency in inhibiting the lipid-mediated pro-inflammatory activity. However, they were reported to cause serious gastrointestinal (GI) side effects and adversely affect platelet function. Hence it is required to identify potential drugs without any side effects. In recent times, bioactive natural products are holding on huge interest regarding the inhibition of cancers and several other inflammatory disorders with minimum or no side effects.

It has been well established that Secreted phospholipases $\mathrm{A}_{2}\left(\mathrm{sPLA}_{2}\right)$ has a crucial role in several inflammatory diseases, including various cancers. Many research organisations have been putting considerable efforts to develop or discover potential sPLA $\mathrm{A}_{2}$ inhibitors as therapeutic or preventive agents. ${ }^{2}$ Numerous studies have recognised several sPLA inhibitors and have been successful at pre-clinical stages. At present, their potential concerning clinical trials for inflammatory diseases, including cancer is in progress. ${ }^{3}$

In this paper, an endeavour was made to study Triphala's effect on the $\mathrm{PLA}_{2}$ enzyme activity. Triphala, an ayurvedic formulation, has been gaining relevance recently due to its anti-inflammatory, anti-oncogenic, and anti-viral behavior. ${ }^{4}$ Considering the detrimental effects of $\mathrm{PLA}_{2}$ enzyme in cancer, this research may provide insight into Triphala's regulation in inflammatory and oncologic diseases.
Triphala is an ayurvedic formulation composed of three herbal fruits of native origin in the Indian subcontinent - Terminalia chebula (Haritaki), Emblica officinalis (Amalaki) and Terminalia bellirica (Bibhitaki). Emblica officinalis is cooling in nature. Terminalia bellirica and Terminalia chebula are warm as a fundamental feature making Triphala a tridoshic rasayan, a balancing agent who has beneficial effects on all- Vata, Pitta and Kapha - doshas of Ayurveda. Triphala is useful for internal cleansing and body detoxification as described by Charaka a principal contributor to Ayurveda and authored Charaka Samhita and Susruta Samhita an ancient Sanskrit text on medicine and surgery.

Triphala is endorsed to defend weariness, osmosis, lessens oxidative pressure and irresistible infections like tuberculosis, pneumonia, AIDS, periodontal sicknesses. ${ }^{5}$ It reported reducing the damage considerably due to oxidative stress. ${ }^{6}$ Studies tell that it inhibits the growth of Grampositive and Gram-negative bacteria. ${ }^{7}$ The recent studies prove that Triphala is rich in gallic acid, Vitamin C, ellagic acid, chebulic acid, bellaricanin, beta-sitosterol and flavonoids. ${ }^{8}$ It is establishing a role in the inhibition of $\mathrm{PLA}_{2}$. A biochemical analysis, anti-oxidation, anti-cancer activity of Triphala done for the present study.

\section{MATERIALS AND METHODS}

\section{Plant material}

Triphala plants (Terminalia bellirica, Terminalia chebula and Emblica officinalis.) fruits collected from forest range of Vikarabad (Dist. 
Vikarabad), Telangana. The fruits were kept in the dark and dry place. The seeds were removed. The fruit wall and pericarp are of primary use. These plants identified as well as recognised by BSI of Deccan Regional Centre, Hyderabad (No: BSI/DRC/17-18/TECH/272). Voucher specimens saved at the Department of Botany Laboratory, SAP Degree and PG College, Vikarabad, Telangana. (Vouchers: SAP/201/2017, SAP/202/2017, SAP/203/2017).

\section{Plant Extract preparation}

The dried fruits of Amla, Haritaki and Bibhitaki rinsed under running water. Surface sterilisation of the fruits was done with $10 \%$ Sodium Hypochlorite solution and washed with distilled water, dry in the room till moisture traces removed from the pericarp. Now dry in the oven at $50^{\circ} \mathrm{C}$. Then powder these dry fruits using blender and grinder. Thus extracted powder was taken in a Soxhlet apparatus $(100 \mathrm{~g}$ in each device) and incubated either with benzene, haloform, acetic ester or methyl alcohol at least for eight hours. ${ }^{9}$ Filter by using a Rota evaporator (Heidolph, Germany) and extracts was filtered, Under decreased pressure at $40^{\circ} \mathrm{C}$ the pooled and solvents were evaporated. For potential use, extracts kept at $4^{\circ} \mathrm{C}$.

\section{Analysis of Gas Chromatography- Mass-Spectrum}

Bioactive compounds details have been collected in the extracts PerkinElmer GC $(30 \mathrm{~mm} \times 0.25 \mathrm{~mm} \times 0.25 \mathrm{~mm})$ (Clarus $680 \mathrm{GC})$. Helium has been used to hold gas $(1 \mathrm{ml} / \mathrm{mL}$ flow rate). Samples were injected, and the oven temperature was scheduled to build $10^{\circ} \mathrm{C} / \mathrm{min}$ $\left(60^{\circ} \mathrm{C}\right.$ to $\left.300^{\circ} \mathrm{C}\right)$ temperature gradient The scale of mass scans was 50 to $600 \mathrm{Da}$. The result was an $\mathrm{m} / \mathrm{z}$ value. ${ }^{10}$ Based on the database collected from the National Institute Standard and Technology (NIST), MassSpectrum and Gas Chromatography was done where it has patterns of more than 62,000 . In the NIST library, the known components were already available and unknown parts where paired. Name of the Test materials, their molecular weight, and elements structure were appropriately listed.

\section{Biochemical Analysis}

Phytochemical investigation for major phytoconstituents of the plant concentrates embraced utilising standard subjective techniques as portrayed by different creators. ${ }^{11}$ The plant concentrates screened for the nearness of naturally dynamic mixes like glycosides, alkaloids, flavonoids, phenolic combinations, saponin, steroids, quinine and tannin. Synthetic tests led on the liquid concentrate of ${ }^{12}$ each example utilising standard techniques. ${ }^{13}$ The five foci arranged are tried for the nearness of phytochemicals. ${ }^{14}$

\section{Antioxidantal Property}

An oxidant usually appears as a molecule when its uses have pertained to biological functions with highly reactive oxygen and nitrogen that make hydroxyl radical, superoxide anion, hydrogen peroxide, nitric oxide, peroxynitrite, lipid peroxide, thiobarbituric acid reactive. The highly reactive radicals oxidatively endogenously convert lipids to lipid peroxyl radicals. Free radicals released by damaging cells ${ }^{15}$ result in releasing free radicals which are of no significance. This occurs during cell metabolism and in response to external factors. If it is difficult for the body to remove the free radicals effectively, oxidation stress occurs. This causes harm to cells and their functions. Oxidative stress leads to ageing, respiratory disorders, cataracts, arthritis, brain dysfunctions, immune deficiency, cancer, heart diseases, and other inflammatory conditions. ${ }^{16,17}$ Natural oxidants save cells from oxidative damage by deactivation and neutralisation of free radicals. ${ }^{18,19}$

\section{DPPH radical scavenging activity}

1,1-Diphenyl-2-picrylhydrazyl (DPPH) radical scavenging activity on Triphala powder extract in methanol gives coloured DPPH The $3 \mathrm{ml}$ reaction mixture comprises of DPPH and Triphala powder extract. Maximum absorption of DPPH at $516 \mathrm{~nm}$ is inversely proportional to the concentration of the extract. This subject to the scavenging potential of Triphala extracts which indicates the half-maximal inhibitory concentration $\left(\mathrm{IC}_{50}\right)$. This shows a $50 \%$ reduction in absorption of the test solution.

\section{Formula}

percentage of DPPH radical scavenging activity $=\left(\left(\mathrm{A}_{0}-\mathrm{A}_{1}\right) / \mathrm{A}_{0}\right) * 100$ In this, $\mathrm{A}_{0}=$ absorbance control $\mathrm{A}_{1}=$ absorbance of Extract or standard $\mathrm{IC}_{50}$ is calculated by plotting a graph taking a percentage of inhibition to concentration. This was done three times at different concentrations.

\section{Assay on Hydrogen peroxide scavenging}

This was done on hydrogen peroxide solution having Triphala powder extract with $50-500 \mu \mathrm{g} / \mathrm{ml} .2 \mathrm{~m} \mathrm{~mol} / \mathrm{L}$ of hydrogen peroxide was prepared in phosphate buffer (PH 7.4) to $(0.60 \mathrm{~L})$ of hydrogen peroxide solution, ${ }^{20}$ polyphenol extract, ascorbic acid and add 1 to $50 \mu \mathrm{g} / \mathrm{ml}$ of extract to it. $3.3 \mathrm{ml}$ of phosphate buffer is added to $0.5 \mathrm{ml}$ of extract to prepare Blank solution. The absorbance after $10 \mathrm{~min}$, at $230 \mathrm{~nm}$, of hydrogen peroxide, was tested. It results that a blank solution does not have hydrogen peroxide but only has a phosphate buffer. This is compared with ascorbic acid, which acts as a reference compound. At each level, the experiment was repeated three times.

Percentage of hydrogen peroxide scavenging activity $=\left[A_{0}-\left(A_{1}-A_{2}\right)\right] X$ $100 / \mathrm{A}_{0}$

$\mathrm{A}_{0}$ refers to an absorbance of control before the addition of sample, $\mathrm{A}_{1}$ refers to absorbance after adding 2-deoxy-D-ribose, and sample $A_{2}$ refers to the absorbance of the sample without 2-deoxy-D-ribose. By using these values, we need to plot a graph to identify the value of $\mathrm{IC}_{50}$. The graph was plotted for the percentage of inhibition to the concentration of the sample.

\section{In vitro phospholipase $\mathrm{A}_{2}$ assay}

Triphala's anti-inflammatory activity is found by using the phospholipase $\mathrm{A}_{2}$ assay kit purchased from Cayman Chemical Ann Arbor, Michigan-48108, USA according to manufacturer's guidance. The reaction mixture contains $10 \mu \mathrm{l}$ of PLA $_{2}$ dissolved in buffer solution (assay) and plant extract at different concentration added to test well of a microtiter plate $200 \mu \mathrm{l}$ of substrate solution present in test-well incubated at $25^{\circ} \mathrm{C}$ for $15 \mathrm{~min}$. Free thiols are released due to hydrolysis activity of PLA ${ }_{2}$ which react with DTNB (5,5'-dithiol-bis-(2-nitrobenzoic acid) which has an absorbance at $415 \mathrm{~nm}$ after incubation $10 \mu \mathrm{l}$ of $5,5^{\prime}$-dithiolbis-2-nitrobenzoic acid) was added into each well. This developed color which has an absorbance at $415 \mathrm{~nm}$ Solvent and sPLA 2 acts as a primary activator (IA) in the reaction mixture where buffer solvent acts as blank. PC -Thioethramide acts as +ve control in that. ${ }^{21}$

Thioethramide -PC has microplate reader of $420 \mathrm{~nm}$. We can measure the percentage of inhibition by using this formula: Percentage of inhibition = ((Absorbance of control - Absorbance of test /The absorbance of control) $\mathrm{X}$ 100) Standard regression log curve obtained by plotting percentage inhibition against the combined value of the concentration of Extract and $\mathrm{IC}_{50}$. 


\section{In silico analysis}

\section{Retrieval of protein structure}

As mentioned earlier phospholipases from several venoms have been reported to play an essential role in inflammation and proliferation pathways. From RSCB protein data bank the protein crystal structure of proteins (1DB5) Humans-PLA, (1LQH) scorpion toxin venom, (1POC) bee-venom phospholipase $\mathrm{A} 2$ and $(1 \mathrm{~A} 3 \mathrm{D})$ phospholipase $\mathrm{A}_{2}\left(\mathrm{PLA}_{2}\right)$ from Naja naja venom were collected from the protein data bank of $\mathrm{RCSB}^{22}$ For conducting molecular docking studies the water and other hetero molecules were removed from the original protein's structure. Using the Swiss Protein Viewer, analysis of Active site was performed. ${ }^{23}$

\section{Retrieval of ligands}

After GC-MS analysis of Triphala powder, 3D structures of various active compounds were identified and retrieved in SDF format from NCBI Pub Chem Compounds [National Center for Biotechnology Information]. Using ChemSpider 2D structures were sketched. The names and Compound ID numbers of the compounds are (CID:445639) Oleic acid, (544150) Tricyclo, (32801) Androstane, (8141)Nonane, (588380)Methyl 3-ethylpent-2-enoate, (137530) 5-Undecyne, (554144) Methyl 10-methyl undecanoate, (6780) 9,10-Anthraquinone, (5280590) MethyElaidate, (5364768) AC1NSKA3, (5363293) (z)-13-octadecenyl acetate (5281670) Morin (using mod inspiration 3D structure was generated). Molinspiraton is a cheminformatics software for calculation of molecular properties, production of bioactivity, virtual screening, and molecular databases.

\section{Grid preparation and molecular Docking}

Using iGEMDOCK, ${ }^{24}$ Autodock Vina, and MGL tools, Molecular Docking was performed. ${ }^{25}$ In MGL tools a pop up comes as AutoDock tools. In this, we can create Docking Input files. For performing Docking selected macromolecules and ligands were chosen Ligands and proteins transformed the PDB files in an Extended PDB format known as PDBQT for molecular docking ADV analytics. Docking was achieved in the grid box's size 40 X 40 X 40 spacing of $1 \AA$. The pdbqt output files have been developed in a Configuration. In a configuration (Settings), the lowest concentration the most stable conformation of binding energy has been shown in the macromolecule-related ligand. The findings have been analysed by Biova Discovery Studio 2020 client Free Edition. (https:// www.3dsbiovia.com/)

\section{RESULTS}

\section{Gas Chromatography to isolate Triphala extract compounds}

Using gas chromatography technique, it is analysed that Triphala extract comprises 12 different compounds tested for their purity and separated as a part of analytical chemistry. all compounds are shown in the Table 1.

\section{Phytochemical Analysis}

Phytochemicals are found to possess a large variety of activities which facilitate protection against chronic diseases. The Triphala pulverised extract has been screened for phytochemical constituents in 5 completely different solvents like water, acetone, chloroform, fuel and ethanol. The preliminary phytochemical analysis discovered the presence of a total of eleven compounds like carbohydrates, tannins, steroids, terpenoids, alkaloids, flavonoids, internal organ glycosides, oils, saponins, coumarins, gum and mucilage.

\section{Radical scavenging activity of DPPH}

Methanolic Triphala powder extract showed unusual and measurable radical scavenging activity of DPPH. The percentage of inhibition is 23.5, $39.23,78.25$ at $1,10,50 \mu \mathrm{g} / \mathrm{ml}$. The concentration of powder extract, $\mathrm{IC}_{50}$ value of seed coat extract is $23.12 \mu \mathrm{g} / \mathrm{ml}$ whereas standard, i.e. superoxide is at $32.66 \mu \mathrm{g} / \mathrm{ml}$. respectively (Table 2).

\section{Scavenging assay of Hydrogen peroxide}

Triphala powder is rich in polyphenolics which acts as a scavenger. Triphala added to hydrogen peroxide in a specific concentration $\left(r^{2}=\right.$ 0.9581 Figure) with $\mathrm{IC}_{50}$. The $\mathrm{IC}_{50}$ value for Hydrogen peroxide is 31.18 $\mu \mathrm{g} / \mathrm{ml} . \mathrm{IC}_{50}$ value of ascorbic acid is $32.66 \mu \mathrm{g} / \mathrm{ml}\left(r^{2}=0.9254,\right)$. Its weak oxidising capacity inactivates capacity; it inactivates some enzymes by oxidising essential thiol group. Hydrogen peroxide can quickly move through the layers of cell membranes and intracellularly reacts with divalent cations like $\mathrm{Fe}^{2+}$ and $\mathrm{Cu}^{2+}$ resulting in the formation of potent hydroxyl radicals oxidising agents. Hence, this has a toxic impact on phenolic compounds as they freshly donate hydrogen and thereby behave as potential free radical scavengers (Table 2).

\section{$\mathrm{PLA}_{2}$ assay results}

Triphala powder's ability comprises the dried fruit wall; pericarp extracts of Phyllanthus emblica, Terminalia chebula, Terminalia bellirica in ethanol at various concentrations in $\mu \mathrm{g} / \mathrm{ml}$ in vitro conditions are checked for it potential strength inhibiting the activity of PLA ${ }_{2}$. This was in turn compared with a positive control Thioethramide - PC. The $\mathrm{IC}_{50}$ values were calculated on digital analogues by organising the data in Microsoft Excel sheet. The $\mathrm{IC}_{50}$ value of Triphala powder was found to be $2.14 \mathrm{ug} / \mathrm{ml}$ and that of the positive control Thioethramide - PC has an $\mathrm{IC}_{50}$ value of $78.1 \mu \mathrm{g} / \mathrm{ml}$. This gave complete clarity as to the effective inhibition of phospholipase $\mathrm{A}_{2}$ by the constituents of Triphala plants and thus is very much suitable for its application in the treatment of inflammatory and oncological diseases. (Figure 1).

\section{In silico Results}

By Molecular Docking, we can get X-ray crystal structures of different proteins. For Docking, sPLA 2 and its types were collected from Protein Data Bank. The ID's of the sPLA 2 proteins obtained from Protein Data Bank is -PDB ID: 1A3D, 1POC, $1 \mathrm{DB} 5$ and $1 \mathrm{LQH}$. By using Argus lab, it is easy to remove water molecules and co-crystallised ligands from target proteins. Useful ligands were prepared by using chem office (Cambridge, UK). Using molecular machines, energy minimised to the root mean square value is less than $0.001 \mathrm{Kcal} / \mathrm{mol}$. Energy minimised receptors and ligands used for Docking. Docking was done by using GEMDOCK (Generic Evolutionary Method for Molecular DOCKing). Empirical scoring function method was used for molecular Docking in GEMDOCK. ${ }^{26}$ For visual interactions, Virtual screening tool like AutoDockVina, ${ }^{27}$ Discovery studio $2020 .^{28}$ (Table 3) According to in

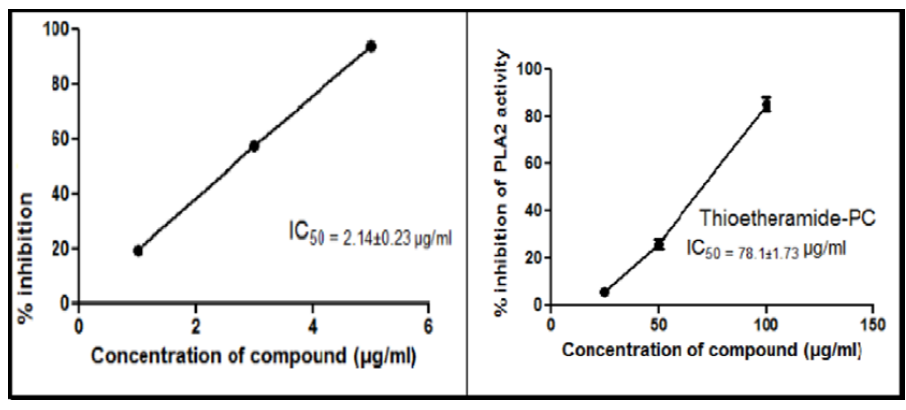

Figure 1: Effect of Triphala Extract on PLA2 activity. 
Table 1: Different Molecular structures and its PubChem codes isolated from Triphala powder from GC-MS.

\begin{tabular}{|c|c|c|c|c|c|c|}
\hline $\begin{array}{l}\text { Ligand } \\
\text { No. }\end{array}$ & GC-MS Code & $\begin{array}{l}\text { PubChem } \\
\text { CID code }\end{array}$ & IUPAC Name & $\begin{array}{l}\text { Chemical } \\
\text { formula }\end{array}$ & Mol. Wt. & Chemical formula \\
\hline 1. & $112-80-1$ & 445639 & Oleic acid (abundant fatty acid) & $\mathrm{C}_{18} \mathrm{H}_{34} \mathrm{O}_{2}$ & $282.468 \mathrm{~g} / \mathrm{mol}$ & \\
\hline 2. & $56666-78$ & 544150 & Tricyclo[4.2.0.02,4]oct-7-en-5-one & $\mathrm{C}_{8} \mathrm{H}_{8} \mathrm{O}$ & $120.151 \mathrm{~g} / \mathrm{mol}$ & \\
\hline 3. & $25126-7$ & 32801 & Androstanediol & $\mathrm{C}_{19} \mathrm{H}_{32} \mathrm{O}_{2}$ & $292.463 \mathrm{~g} / \mathrm{mol}$ & \\
\hline 4. & $111-84-2$ & 8141 & Nonane & $\begin{array}{l}\mathrm{H}_{3} \mathrm{C}^{-}\left(\mathrm{CH}_{2}\right) 7- \\
\mathrm{CH}_{3} \text { or } \mathrm{C}_{9} \mathrm{H}_{20}\end{array}$ & $128.259 \mathrm{~g} / \mathrm{mol}$ & \\
\hline 5. & 13979-17 & 588380 & Methyl 3-ethylpent-2-enoate & $\mathrm{C}_{8} \mathrm{H}_{14} \mathrm{O}_{2}$ & $142.198 \mathrm{~g} / \mathrm{mol}$ & \\
\hline 6. & $2294-72-6$ & 137530 & 5-Undecyne & $\mathrm{C}_{11} \mathrm{H}_{20}$ & $152.281 \mathrm{~g} / \mathrm{mol}$ & \\
\hline 7. & $5129-56-6$ & 554144 & Methyl 10-methylundecanoate & $\mathrm{C}_{13} \mathrm{H}_{26} \mathrm{O}_{2}$ & $214.349 \mathrm{~g} / \mathrm{mol}$ & \\
\hline 8. & $84-65-1$ & 6780 & ANTHRAQUINONE & $\begin{array}{c}\mathrm{C}_{6} \mathrm{H}_{4}(\mathrm{CO})_{2} \mathrm{C}_{6} \mathrm{H}_{4} \\
\text { or } \\
\mathrm{C}_{14} \mathrm{H}_{8} \mathrm{O}_{2}\end{array}$ & $208.216 \mathrm{~g} / \mathrm{mol}$ & \\
\hline 9. & $2462-84-2$ & 5280590 & MethyElaidate & $\mathrm{C}_{19} \mathrm{H}_{36} \mathrm{O}_{2}$ & $296.495 \mathrm{~g} / \mathrm{mol}$ & \\
\hline 10. & $\mathrm{DB} \# 17439$ & 5364768 & $\begin{array}{c}\text { AC1NSKA3 or E,E,Z-1,3,12- } \\
\text { Nonadecatriene-5,14-diol }\end{array}$ & $\mathrm{C}_{19} \mathrm{H}_{34} \mathrm{O}_{2}$ & $294.479 \mathrm{~g} / \mathrm{mol}$ & \\
\hline 11. & $60037-58$ & 5363293 & $\begin{array}{l}\text { (z)-13-octadecenyl acetate (or) } \\
\text { 13-Octadecenyl acetate, (13Z) }\end{array}$ & $\mathrm{C}_{20} \mathrm{H}_{38} \mathrm{O}_{2}$ & $310.522 \mathrm{~g} / \mathrm{mol}$ & \\
\hline 12. & $480-16-0$ & 5281670 & Morin & $\mathrm{C}_{15} \mathrm{H}_{10} \mathrm{O}_{7}$ & $302.238 \mathrm{~g} / \mathrm{mol}$ & \\
\hline
\end{tabular}

silico studies, high compound 12 (with $-100.48 \mathrm{~K} . \mathrm{cal} / \mathrm{mol}$ ) binds to the amino acid residue's different active site. The active sites are ARG-30, HIS-47, GLY-29, ASP-48, ARG-30, PHE-5, TYR-63, GLY-29, CYS-28, TRP-18, HIS-47 and TYR-51. Compound $10(-91.7382 \mathrm{~K} . \mathrm{cal} / \mathrm{mol})$ the second highest protein binds to amino acid residues at different sites. These sites are ALA-22, PHE-5, GLY-29, TRP-18, CYS-28, HIS-47, TYR63 and ARG-30. These two are vital in binding with sPLA 2 (1A3D) so that they enhance $\mathrm{SLA}_{2}$-inhibitory action.

According to in silico, the highest compound $12(-110.298 \mathrm{~K} . \mathrm{cal} / \mathrm{mol})$ can bind freely at different amino acid residues' active sites. The various active sites are THR-57, HIS-34, CYS-9, ASP-35, PHE-67, TYR-87, VAL83 and GLY-10. The second highest is compound $03(-96.1492 \mathrm{~K} . \mathrm{cal} / \mathrm{mol})$ can bind freely to different active sites of the amino acid residues. The various active sites are TYR-87, CYS-9, ASP-35, HIS-34, GLY-10 and
TYR-3. Both have good interaction and strong binding capacity with sPLA2 (1POC), which may also show its inhibitory activity.

According to in silico, the highest compound 12 (-95.5282K.cal $/ \mathrm{mol})$ can bind at different amino acid residues' active sites. The various active sites are HIS-47, GLY-22, CYS-44, GLY-29, ALA-18, ALA-17, PHE-5, HIS- 6 and CYS-28. The second highest one is compound $01(-81.3528 \mathrm{~K}$. $\mathrm{cal} / \mathrm{mol}$ ) can bind at different active sites of amino acid residues. These various active sites are ARG-7, CYS-44, GLY-29, TYR-21, HIS-6, LEU-2 and VAL-3 (Figure 2). Both of these have high interaction and strong binding capacity with sPLA 2 (1DB5). This may show sPLA 2 -inhibitory action more.

According to in silico studies, the first more excellent compound 12 $(-82.6534 \mathrm{~K} . \mathrm{cal} / \mathrm{mol})$ can bind at different amino acid residues' active sites. These different active sites are PRO-61, GLY-62, ARG-59, LYS42, VAL-60, TYR-6 and LYS-42. The second highest compound, 11 
Table 2: DPPH radical scavenging activities, Hydrogen peroxide scavenging activities from Triphala plant extracts.

\begin{tabular}{|c|c|c|c|}
\hline Sample & $\begin{array}{l}\text { Concentration of } \\
\text { extract }(\mu \mathrm{g} / \mathrm{ml})\end{array}$ & $\%$ of inhibition & $\begin{array}{c}I C_{50}(\mu \mathrm{g} / \\
\mathrm{ml})\end{array}$ \\
\hline \multicolumn{4}{|c|}{ DPPH radical scavenging activity } \\
\hline \multirow[t]{3}{*}{ Triphala powder } & $1 \mu \mathrm{g} / \mathrm{ml}$ & 23.50 & \\
\hline & $10 \mu \mathrm{g} / \mathrm{ml}$ & 41.23 & 23.12 \\
\hline & $50 \mu \mathrm{g} / \mathrm{ml}$ & 78.23 & \\
\hline \multirow[t]{3}{*}{ Superoxide } & $1 \mu \mathrm{g} / \mathrm{ml}$ & 21.87 & \\
\hline & $10 \mu \mathrm{g} / \mathrm{ml}$ & 39.23 & 32.66 \\
\hline & $50 \mu \mathrm{g} / \mathrm{ml}$ & 61.67 & \\
\hline \multicolumn{4}{|c|}{ Hydrogen peroxide scavenging activity } \\
\hline \multirow[t]{3}{*}{ Triphala powder } & $1 \mu \mathrm{g} / \mathrm{ml}$ & 22.8 & \\
\hline & $10 \mu \mathrm{g} / \mathrm{ml}$ & 38.12 & 31.18 \\
\hline & $50 \mu \mathrm{g} / \mathrm{ml}$ & 63.78 & \\
\hline \multirow[t]{3}{*}{ Superoxide } & $1 \mu \mathrm{g} / \mathrm{ml}$ & 21.87 & \\
\hline & $10 \mu \mathrm{g} / \mathrm{ml}$ & 39.23 & 32.66 \\
\hline & $50 \mu \mathrm{g} / \mathrm{ml}$ & 61.67 & \\
\hline
\end{tabular}

Table 3: different proteins (1 a3d, 1 poc, 1 db5, 1 lqh) docking with 12 ligands (triphala plant extracts from GC-MS).

\begin{tabular}{|c|c|c|c|c|}
\hline \multicolumn{5}{|c|}{ 1a3d (NAJA NAJA VENOM )protein with effect on Triphala } \\
\hline Ligand & Total Energy & VDW & H Bond & Aver ConPair \\
\hline 1 & -78.794 & -72.1604 & -6.63355 & 21.9 \\
\hline 2 & -51.8051 & -44.8051 & -7 & 28.2222 \\
\hline 3 & -65.1567 & -55.7116 & -9.44515 & 22 \\
\hline 4 & -47.7716 & -47.7716 & 0 & 33.3333 \\
\hline 5 & -57.2889 & -47.8226 & -9.46627 & 32.7 \\
\hline 6 & -54.7596 & -54.7596 & 0 & 32.9091 \\
\hline 7 & -65.1428 & -56.0618 & -9.08102 & 23.8 \\
\hline 8 & -84.2251 & -79.2607 & -4.96442 & 34.125 \\
\hline 9 & -69.9563 & -63.9563 & -6 & 20.1905 \\
\hline 10 & -91.7382 & -87.7651 & -3.97315 & 25.8095 \\
\hline 11 & -81.5762 & -78.871 & -2.70525 & 23.3182 \\
\hline 12 & -100.48 & -80.574 & -19.9058 & 31.6364 \\
\hline \multicolumn{5}{|c|}{1 poc (BEE-VENOM) protein with effect on Triphala } \\
\hline Ligand & Total Energy & VDW & H Bond & Aver ConPair \\
\hline 1 & -87.7866 & -87.7866 & 0 & 27.5 \\
\hline 2 & -53.1556 & -47.9948 & -5.16078 & 33.5556 \\
\hline 3 & -96.1492 & -86.5208 & -9.62831 & 28.5714 \\
\hline 4 & -46.6357 & -46.6357 & 0 & 29.4444 \\
\hline 5 & -60.3823 & -51.5276 & -8.85465 & 31.7 \\
\hline 6 & -56.5714 & -56.5714 & 0 & 30.7273 \\
\hline 7 & -68.2334 & -58.743 & -9.49046 & 26.9333 \\
\hline 8 & -84.7662 & -77.1805 & -7.58566 & 28.4375 \\
\hline 9 & -87.425 & -86.49 & -0.93506 & 27.0952 \\
\hline 10 & -95.1116 & -95.1116 & 0 & 28.0476 \\
\hline 11 & -74.9631 & -74.9631 & 0 & 23.5455 \\
\hline 12 & -110.298 & -93.8519 & -16.4456 & 31.0455 \\
\hline
\end{tabular}

\section{Table 3: Con'}

\begin{tabular}{|c|c|c|c|c|}
\hline \multicolumn{5}{|c|}{ 1db5 (HUMAN S-PLA2) protein with effect on Triphala } \\
\hline Ligand & Total Energy & VDW & H Bond & Aver ConPair \\
\hline 1 & -81.3528 & -72.217 & -9.1359 & 22.45 \\
\hline 2 & -52.1727 & -43.673 & -8.5 & 34.4444 \\
\hline 3 & -77.0953 & -70.095 & -7 & 24.6667 \\
\hline 4 & -43.5533 & -43.553 & 0 & 28.5556 \\
\hline 5 & -58.7965 & -45.272 & -13.525 & 27.9 \\
\hline 6 & -52.9255 & -52.926 & 0 & 30.9091 \\
\hline 7 & -70.0985 & -51.099 & -19 & 22.4667 \\
\hline 8 & -74.1342 & -68.159 & -5.9751 & 26.5625 \\
\hline 9 & -73.7015 & -69.049 & -4.6523 & 23.8095 \\
\hline 10 & -80.4446 & -78.983 & -1.4616 & 23.7619 \\
\hline 11 & -68.2214 & -62.877 & -5.3443 & 18.4545 \\
\hline 12 & -95.5282 & -83.263 & -12.265 & 25.6364 \\
\hline \multicolumn{5}{|c|}{ 1lqh (VENOM OF SCORPION) protein with effect on Triphala } \\
\hline Ligand & total energy & VDW & H Bond & Aver ConPair \\
\hline 1 & -70.9284 & -60.911 & -10.017 & 22.35 \\
\hline 2 & -47.7236 & -38.997 & -8.7268 & 29 \\
\hline 3 & -68.7244 & -61.724 & -7 & 24.1429 \\
\hline 4 & -41.869 & -41.869 & 0 & 28.3333 \\
\hline 5 & -47.113 & -42.001 & -5.1121 & 25.7 \\
\hline 6 & -49.4851 & -49.485 & 0 & 26.5455 \\
\hline 7 & -56.9988 & -53.557 & -3.4417 & 23.2 \\
\hline 8 & -66.6953 & -56.903 & -9.7922 & 26.1875 \\
\hline 9 & -72.9598 & -72.96 & 0 & 20.8095 \\
\hline 10 & -63.0735 & -57.921 & -5.1525 & 18.8095 \\
\hline 11 & -73.9662 & -71.466 & -2.5 & 22.6364 \\
\hline 12 & -82.6534 & -68.992 & -13.661 & 26.6818 \\
\hline
\end{tabular}

Ligand Code: 1.Oleic acid, 2.Tricyclo, 3.Androstane, 4.Nonane, 5.Methyl 3-ethylpent-2-enoate, 6.5-Undecyne, 7. Methyl 10- methyl undecanoate; 8. ANTHRAQUINONE, 9.MethyElaidate, 10. AC1NSKA3, 11.(z)-13-octadecenyl acetate, 12.Morin

(-73.9662K.cal $/ \mathrm{mol})$, can bind to different amino acid residues' active sites. These different active sites are ARG-59, ARG-3, TYR-6, ASP54, TYR-43, LYS-42 and VAL-2. These two have a high capacity for interaction and strong capacity in binding with $\operatorname{sPLA}_{2}(1 \mathrm{LQH})$. This may increase sPLA inhibitory activity. The different docking software such as AutoDock Vina, Virtual tools warns us of this type of inhibitory activity of sPLA $_{2}$ (increase or decrease). Docking scores can be scheduled, and the values were listed in (Table 3). Protein-ligand interaction 3D and 2D graphical structures are mentioned in (Figure 2).

\section{DISCUSSION}

Indian Ayurveda that human body is a combination of 3 elements known as doshas like Vatha dosha (space and air) which allows motility; Pitta dosha (water and fire) allows to change, helps in proper digestion and metabolic activities; Kapha dosha (earth and water) which gives the structure. These three doshas let body organs work in harmony and create 


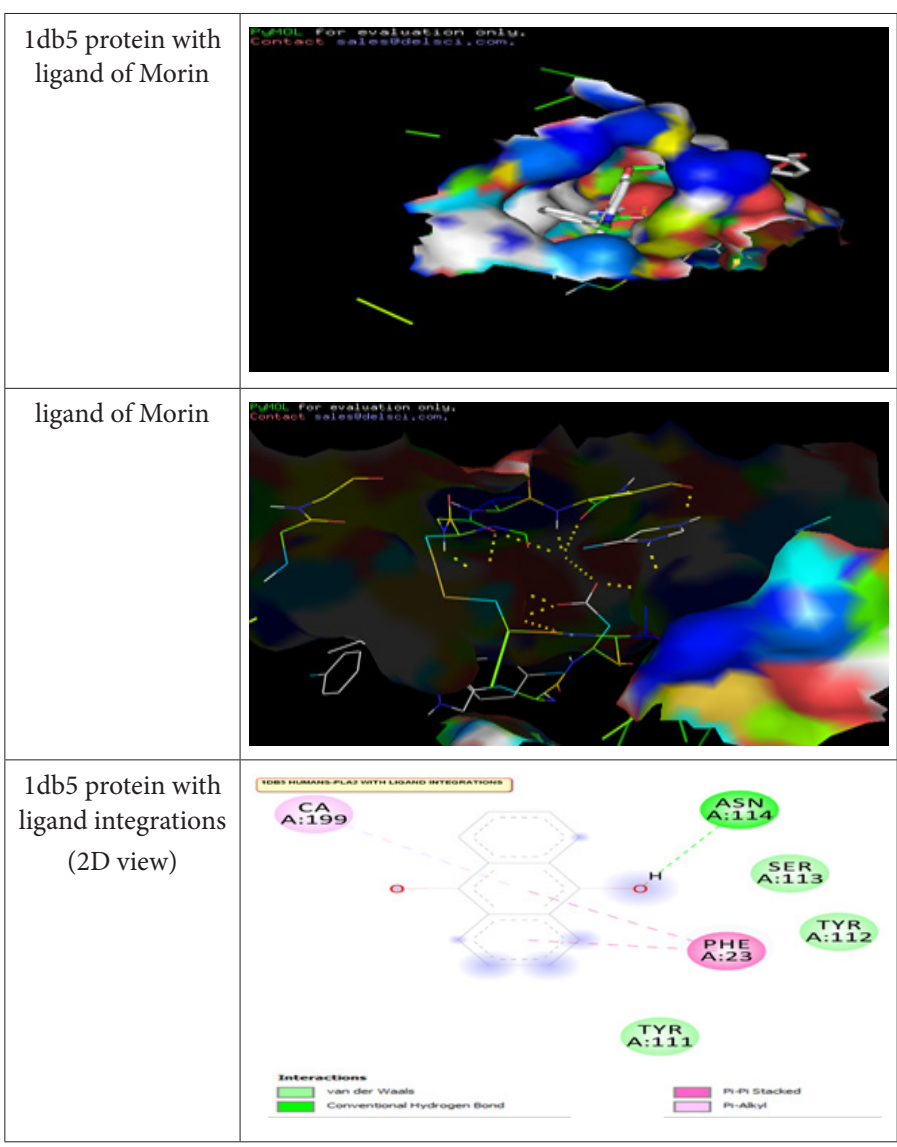

Figure 2: $1 \mathrm{db} 5$ protein with morin ligand docking study with $3 \mathrm{D}$ and $2 \mathrm{D}$ view.

man's relationship with the environment and the universe. The given study is about Triphala constituents' inhibitory activity on phospholipase A2 and application in treating oncological diseases and inflammation. Triphala powder is a combination of fruit walls, or pericarp of the fruits from three plants Phyllanthus emblica, Terminalia chebula, Terminalia bellirica samples of each of these constituents of Triphala are collected and tested for their inhibitory activity on $\mathrm{PLA}_{2}$ enzyme. It is then proved that Triphala powder shows the highest degree of inhibition on $\mathrm{PLA}_{2}$ enzyme is achieved with a measure of $2.14 \mathrm{ug} / \mathrm{ml}$.

At the second level, the effect of the compounds of the fruit wall or pericarp of Triphala constituents is being analysed. The analysis results were inferred that the pericarp of the constituent fruits of Triphala is comprised of 12 compounds. The twelve components of the pericarp fruit were isolated using the technique of Gas chromatography. The isolated compounds are docked against the PLA enzyme to get the high binding energy compound and thus conclude it to be most effective.

Using IGEMDOCK, Autodock Vina, software 3D images of the molecular structure twelve secondary metabolites - Oleic acid, Tricyclo oct-7-en-5-one, Androstanediol, Nonane, Methyl 3-ethylpent- 2-enoate, 5-Undecyne, Methyl 10-Methylundecanoate, anthraquinone, Methy Elaidate, ac1nska3, (z)-13- octadecenyl acetate, Morin were generated.

This was all done on bioinformatics, which is an interdisciplinary field and developed software tools for reading, analysing, and interpreting biological data used. Molecular Docking is a bioinformatics modelling that involves interacting with one or two or more molecules to give stable adduct depending on the binding properties of legend and target; it predicts the 3D structure of a complex. Ligand helps to bind the molecules. With the Docking for protein-ligand, the direction and position of the ligand identification were done efficiently. We can easily find out the ligand attached to an enzyme or a protein receptor. The binding energy of all the 12 compounds when superimposed on the protein structure of the $\mathrm{PLA}_{2}$ enzyme is noted down in a tabular form. Only the compounds with over $85 \%$ of binding energy are taken for further research. From the table, it is evident that anthraquinone and Morin has over $85 \%$ of binding energy much more than the rest of Triphala's constituents. So I have preceded Anthraquinone and Morin as further study, and they are the compound of Triphala fruit walls with more significant inhibiting potential against PLA ${ }_{2}$. They give a lead in drug research against cancer and autoimmune system.

\section{CONCLUSION}

The Triphala powder is also found to contain flavonoids, steroids, alkaloids, amino acids, tannins, terpenoids, saponins, phenolic compounds and other organic substances. A detailed phytochemical analysis is carried out to study their presence in Triphala. The study asserts the effect of $\mathrm{PLA}_{2}$ inhibitor successfully. In addition to this result, the survey of lead compounds present in Triphala such as Anthraquinone, ACINSKA3, and Marin helps drug research on cancer and autoimmune diseases.

\section{ACKNOWLEDGEMENT}

The heartfelt thanks to Dr M. K. Arunasree, Department of Life Science, Hyderabad Central University, Hyderabad India and Dr G.V. Reddy Garu (Scientific Officer) Hyderabad Central University, Hyderabad, India were provided with necessary guidelines to complete my work.

\section{CONFLICT OF INTEREST}

Writers whose names are immediately set out below certify that they have NO affiliations with or involvement in any association or corporation with any financial benefit (such as honoraria; educational grants; participation in speaker's offices; membership, jobs, consulting, shareholding or other stock interest; and expert testimony or patentlicensing arrangements) or non-financial guidance.

\section{ABBREVIATIONS}

PLA $_{2}$ : Phospholipase $\mathrm{A}_{2} ;$ IC $_{50}$ : Half maximal inhibitory concentration; $\mu \mathrm{g}$ : Microgram, $\mu \mathrm{l}$ : Microlitre; NSAIDs: Non-steroidal anti-inflammatory drugs; DPPH: 2,2-Diphenyl-1-picrylhydrazyl; DTNB: 5,5'-dithiol-bis(2-nitrobenzoic acid); GEMDOCK: A Generic Evolutionary Method for molecular Docking.

\section{REFERENCES}

1. Chinnasamy S, Selvaraj G, Selvaraj C, Kaushik AC, Kaliamurthi S, Khan A, et al. Combining in silico and in vitro approaches to identification of potent inhibitor against phospholipase A2. Int J Biol Macromol. 2020;144:53-66.

2. Dennis EA, Cao J, Hsu YH, Magrioti V, Kokotos G. Phospholipase A2Enzymes: Physical structure, biological function, disease implication, chemical inhibition, and therapeutic intervention. Chem Rev. 2011;111(10):6130-85.

3. Quach ND, Arnold RD, Cummings BS. Secretory phospholipase A2 enzymes as pharmacological targets for the treatment of disease. Biochem Pharmacol. 2014;90(4):338-48.

4. Kim RR, Chen Z, J. Mann T, Bastard K, F. Scott K, Church WB. Structural and functional aspects of targeting the secreted human group IIA phospholipase A2. Molecules. 2020;25(19):4459.

5. Shivaprasad BM, Patil P, Nair S, Singh N, Shivan S, Sameera U. Triphala: A phytomedicine for local drug delivery: A strategic intervention. AYU. 2019;40(1):53

6. Prasad S, Srivastava SK. Oxidative stress and cancer: Chemopreventive and therapeutic role of Triphala. Antioxidants. 2020;9(1):72.

7. Achika JI, Ayo RG, Oyewale AO, Habila JD. Flavonoids with antibacterial and antioxidant potentials from the stem bark of Uapaca heudelotti. Heliyon. 2020;6(2):e03381.

8. Omran Z, Bader A, Porta A, Vandamme T, Anton N, Alehaideb Z, et al. Evaluation of the antimicrobial activity of Triphala constituents and nanoformulation. Evid 
Based Complement Alternat Med. 2020;2020:1-11.

9. Kumar S, Kumari R, Mishra S. Pharmacological properties and their medicinal uses of Cinnamomum: A review. J Pharm Pharmacol. 2019;71(12):1735-61.

10. Gopi K, Anbarasu K, Renu K, Jayanthi S, Vishwanath BS, Jayaraman G. Quercetin-3-O-rhamnoside from Euphorbia hirta protects against snake Venom induced toxicity. Biochimica et Biophysica Acta (BBA)-General Subjects. 2016;1860(7):1528-40

11. Ha MT, Vu NK, Tran TH, Kim JA, Woo MH, Min BS. Phytochemical and pharmacological properties of Myristica fragrans Houtt: An updated review. Arch Pharm Res. 2020:43(11):1067-92.

12. Girardi C, Butaud JF, Ollier C, Ingert N, Weniger B, Raharivelomanana $P$, et al. Herbal medicine in the Marquesas islands. J Ethnopharmacol. 2015:161:200-1.

13. Edeoga HO. Department of 1 Biological and 2 Chemical Sciences Michael Okpara University of Agriculture, Umudike P.M.B 7267, Umuahia, Abia State, Nigeria. Okwu DE, Mbaebie BO. Phytochemical constituents of some Nigerian medicinal plants. Afr J Biotechnol. 2005;4(7):685-8

14. Esmaeili AK, Taha RM, Mohajer S, Banisalam B. Antioxidant activity and total phenolic and flavonoid content of various solvent extracts from Vivoand in vitro Grown Trifolium pretence. (Red clover). Biomed Res Int. 2015;2015:1-11.

15. Nakamura T, Maguro I, Ichijo H. Iron homeostasis and iron-regulated ROS in cell death, senescence and human diseases. Biochim Biophys Acta Gen Subj. 2019;1863(9):1398-409.

16. Lobo V, Patil A, Phatak A, Chandra N. Free radicals, antioxidants and functional foods: Impact on human health. Pharmacogn Rev. 2010;4(8):118.

17. Carocho $M$, Ferreira IC. A review on antioxidants, prooxidants and related controversy: Natural and synthetic compounds, screening and analysis methodologies and future perspectives. Food and Chemical Toxicology. 2013;51:15-25

18. Almeida IMC, Barreira JCM, Oliveira MBPP, Ferreira ICFR. Dietary antioxidant supplements: Benefits of their combined use. Food Chem Toxicol. 2011;49(12):3232-7.

19. Gostner JM, Becker K, Ueberall F, Fuchs D. The good and bad of antioxidant foods: An immunological perspective. Food Chem Toxicol. 2015;80:72-9.

20. Ruch RJ, Cheng SJ, Klaunig JE. Prevention of cytotoxicity and inhibition of intercellular communication by antioxidant catechins isolated from Chinese green tea. Carcinogenesis. 1989;10(6):1003-8.

21. Nataraj A, Raghavendra Gowda C, Rajesh R, Vishwanath B. Group IIA secretory PLA2 inhibition by ursolic acid: A potent anti-inflammatory molecule. Curr Top Med Chem. 2007;7(8):801-9.

22. Berman HM, Battistuz T, Bhat TN, Bluhm WF, Bourne PE, Burkhardt K, et al. The Protein Data Bank. Acta Crystallogr D Biol Crystallogr. 2002;58(6):899-907.

23. Johansson MU, Zoete $V$, Michielin O, Guex N. Defining and searching for structural motifs using DeepView/Swiss-PdbViewer. BMC Bioinformatics. 2012;13(1):173.

24. Poorani S, Swaminathan P. An in silico Workflow that Yields Experimentally Comparable Inhibitors for Human Dihydroorotate Dehydrogenase. Curr Comput Aided Drug Des. 2020;16(3):340-50.

25. Morris GM, Huey R, Lindstrom W, Sanner MF, Belew RK, Goodsell DS, et al. AutoDock4 and AutoDockTools4: Automated docking with selective receptor flexibility. J Comput Chem. 2009;30(16):2785-91.

26. Yang JM, Chen CC. GEMDOCK: A generic evolutionary method for molecular docking. Proteins. 2004;55(2):288-304.

27. Vina A. Improving the speed and accuracy of docking with a new scoring function, efficient optimisation, and multithreading Trott, Oleg; Olson, Arthur J. J Comput Chem. 2010;31(2):455-61.

28. Yang JM. Development and Evaluation of a generic evolutionary method for protein-ligand docking. J Comput Chem. 2004;25(6):843-57.

Article History: Submission Date : 07-02-2021; Revised Date : 04-03-2021; Acceptance Date : 29-03-2021.

Cite this article: Malladi SM, Yarla NS, Pandey DK. Enzyme Inhibition Activity Both in vitro and silico Screening of Triphala Plant Extracts on Phospholipase $A_{2}$. Int. J. Pharm. Investigation, 2021;11(2):158-64. 